\section{The Yin and Yang of medical consultations}

\author{
John Launer
}

I ran a seminar last week on listening to patients' narratives and asked the doctors present if they ever saw patients who talked about their symptoms. It seemed such an absurd question that they all looked alarmed-except for one or two who gave me the indulgent look you receive when people think you are showing signs of cognitive decline. So I repeated my question in a slightly different way. How many of their patients, I asked, ever came into a consultation and say 'My symptoms are...' or indeed used the word 'symptoms' at all? We were then able to have an intelligent discussion about the words that doctors prefer to use and the ones that patients do, along with the different ways that doctors and patients conceptualise the world.

The fact is, patients very rarely come to doctors talking of 'symptoms', apart from a very few who prefer to use that kind of formal language. Instead, they use their own individual words, phrases and stories. They also grimace, make other facial expressions, point to parts of themselves and speak with their bodies, showing us physically, as well as verbally, what they are experiencing. We listen and watchor believe we do-and then we sift these narratives through our medically trained minds and reformulate them. It is we, not they, who then turn their stories into what we call symptoms.

Rather than speaking about symptoms, patients' narratives usually include expressions like 'I don't know what's going on. I seem to get tired very easily'. Unthinkingly, we then tend to write down a stock phrase in their notes like 'Tired all the time', without even noticing that this isn't exactly what the patient said. We may have failed to register a statement like 'I don't know what's going on', dismissing it as mere noise- - even though it was the very first thing the patient said, and may have been a plea for an explanation, or indicated a fear of something fatal. For most of the time, we are totally unaware that we are carrying continual acts of translation

Associate Editor, Postgraduate Medical Journal, London, UK

Correspondence to Dr John Launer, Postgraduate Medical Journal, London WC1H 9JP, UK; johnlauner@aol.com like this, systematically sorting the free flow of the patient's narrative into the norms of understanding and description determined by our own profession. Yet, translating someone else's story into one of our own is what we do all the time. ${ }^{1}$

\section{NARRATIVE AND NORMATIVE REALITIES}

There is, of course, a case for saying that this act of translation is no bad thing. Without the ability to convert the patient's narrative version of reality into our normative one, no meaningful medical action is possible. ${ }^{2}$ Patients by and large do not come to us just to be listened to. They consult us because we have expert knowledge. If doctors cannot work out whether a patient is tired because of anaemia or depression, for instance, or explain what this means, they are of little use. So the problem of medical encounters is not that we turn the patient's story into our own version. It is that, as result, we often miss out an enormous amount of information that matters a great deal to the patient, and might make a big difference to our understanding of the problem as well. Bringing the two stories-theirs and yours-into harmony with each other, can enrich the relationship, leading to conversations and decisions that are genuinely shared.

My colleague Jens Foell, a general practitioner in North Wales, has likened the narrative and normative aspects of medical encounters to the Yin and Yang of Chinese philosophy (figure 1). While seeming to be opposite and contradictory aspects of reality, they are in fact complementary and interdependent. One of my favourite examples of a physician weaving together the Yin and Yang of doctor-patient communication in a seamless way comes from a classic paper by the US sociologist Eliot Mishler and his team, who recorded this brief and very simple exchange between a neurologist and a car mechanic who had just suffered his first seizure ${ }^{3}$ :

Patient: ... my boss hadn't got all the parts for it, so I started working on another car, ya-know? That's when I ended up having the seizure.

Doctor: Okay ... So did your boss or someone else see the seizure happen?

What seems to me exceptional about this conversation (and the reason I often quote it when teaching) is the way the doctor manages both to inhabit the patient's story imaginatively and to carry out his technical task. He shows he has been listening by picking up on the presence of the 'boss' in the patient's story, but he also uses this to find out if there was a witness to the seizure, who might provide an independent account and help to determine the diagnosis. This dual skill—of tracking the narrative and adapting it for a normative purpose-may be something he has learnt through training and experience, or it may be the result of innate empathy. Either way, it stands in impressive contrast to what Mishler describes as the 'unremarkable medical interview' that happens on most occasions, and where doctors routinely process stories in

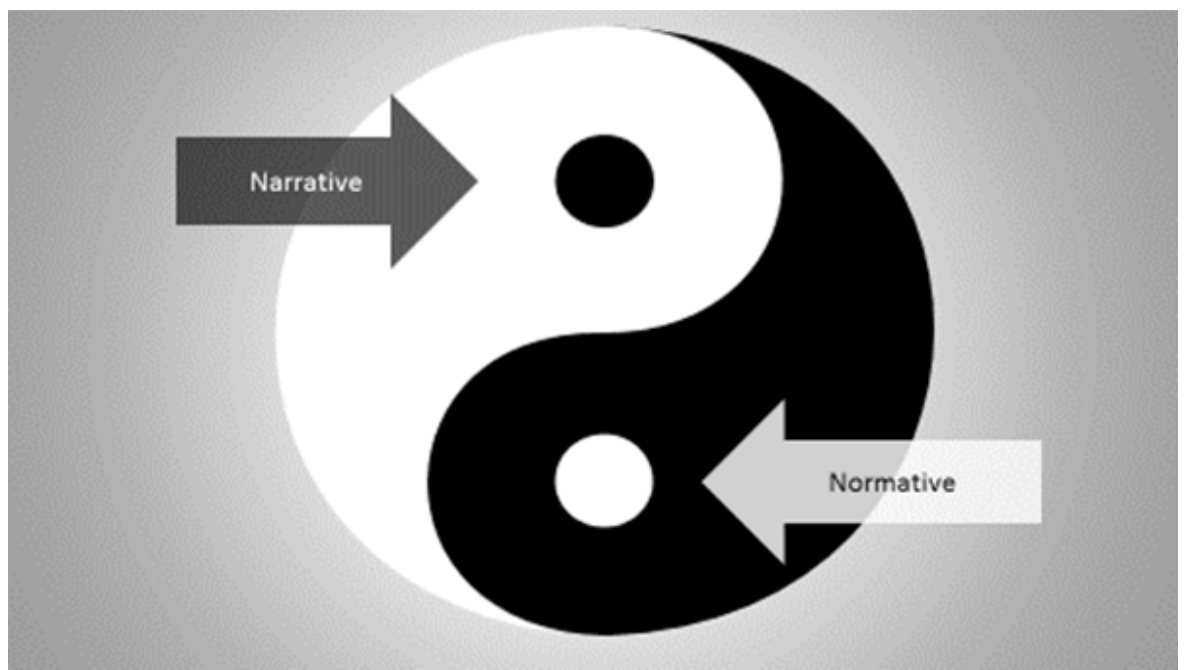

Figure 1 The Yin and Yang of medical consultations 
a way that has some practical utility but is divorced from their patients' subjective experiences.

\section{ETHICAL AND PRAGMATIC}

There is an ethical case for being able to apply attentiveness to a patient's words and gestures in this way, and to be able to do it from moment to moment. It shows respect, and allows doctors to modulate their speech according to the patient's own level of knowledge and understanding. But there are strong pragmatic reasons for doing so too. If patients do not have the impression we are listening and watching attentively, they may not tell us what we need to know, or understand our explanations, follow our advice and accept our treatment. Conversely, conversations that are well-attuned have been shown to lead to fuller disclosure, better diagnosis and decision-making, greater compliance, safer outcomes, fewer complaints and less litigation. ${ }^{4-7}$ 8 So-called 'soft skills', such as active listening and focused inquiry, don't just produce nice, warm feelings. Integrating the Yin and Yang of medical practice can save lives, and medical careers.

Funding The author has not declared a specific grant for this research from any funding agency in the public, commercial or not-for-profit sectors.

Competing interests None declared.

Patient consent for publication Not required.

Provenance and peer review Not commissioned; internally peer reviewed.

(C) Author(s) (or their employer(s)) 2019. No commercial re-use. See rights and permissions. Published by BMJ.

\section{Check for updates}

To cite Launer J. Postgrad Med J 2019;95:575-576.

Postgrad Med J 2019;95:575-576.

doi:10.1136/postgradmedj-2019-136947

\section{REFERENCES}

1 Marshall RJ, Bleakley A. Lost in translation. Homer in English: the patient's story in medicine. Med Hums 2013;39:47-52.

2 Launer J. Narrative-based practice in health and social care: conversations Inviting change. London: Routledge, 2018.

3 Mishler E, Clark JA, Ingelfinger J, et al. The language of attentive patient care: a comparison of two medical interviews. J Gen Int Med 1989;4:325-35.

4 Street RL, Makoul G, Arora NK, et al. How does communication heal? Pathways linking clinician-patient communication to health outcomes. Patient Educ Couns 2009;74:295-301.

5 Kim SS, Kaplowitz S, Johnston MV. The effects of physician empathy on patient satisfaction and compliance. Eval Health Prof 2004;27:237-51.

6 Casal T. Can you die from not being listened to? In: Fernandes I, Martins CB, et al, eds. Creative dialogues: narrative and medicine. Cambridge: Cambridge Scholars, 2015: 80-94.

7 Levinson W, Roter DL, Mullooly JP, et al. PhysicianPatient communication. The relationship with malpractice claims among primary care physicians and surgeons. JAMA 1997;277:553-9.

8 Hargraves I, LeBlanc A, Shah ND, et al. Shared decision making: the need for Patient-Clinician conversation, not just information. Health Aff 2016;35:627-9. 